\title{
Tedarik Zincirinde Risk Değerlendirme: Risklerin Tanımlanması, Gruplandırılması ve Önceliklendirilmesi Üzerine Bir Çalışma \\ (Supply Chain Risk Evaluation: A Study on Identification, Grouping and Prioritization of Risks)
}

Mübeyyen TEPE KÜÇÜKOĞLU iD a

a Trakya Üniversitesi, Keşan Yusuf Çapraz Uygulamalı Bilimler Yüksekokulu, Edirne, Türkiye. mtepekucukoglu@trakya.edu.tr

\begin{tabular}{|c|c|}
\hline MAKALE BİLGİSİ & ÖZET \\
\hline Anahtar Kelimeler: & \multirow{10}{*}{$\begin{array}{l}\text { Amaç - Tedarik zinciri risk yönetimi kapsamında risklerin tanımlanması, sınıflandırılması ve } \\
\text { önceliklendirilmesi hem tedarik zinciri hem de işletme performansı açısından önemli bir konudur. } \\
\text { Bu bakış açısından yola çıkan çalışma, üretim sektöründe faaliyet gösteren işletmelerin tedarik } \\
\text { zincirlerinde karşılaşabilecekleri risklerin neler olduğunun belirlenmesi ve belirlenen risklerin } \\
\text { meydana gelme olasılığı ile gerçekleştireceği etki değerlerinden oluşan risk puanlarının } \\
\text { hesaplanması ile risklerin önceliklendirilerek işletmelere bir yol haritası çıkarmayı amaçlamaktadır. } \\
\text { Yöntem - Araştırmanın örneklemini Kocaeli sınırları içerisinde bulunan üretim faaliyetini çeşitli } \\
\text { sektörlerde devam ettiren } 97 \text { işletme oluşturmaktadır. Anket yöntemi kullanılarak, bu işletmelerin } \\
\text { tedarik zincirlerinde karşılaşabileceği risklerin meydana gelme olasılığı ve gerçekleştiği takdirle } \\
\text { etkisinin ne olacağ1 konusunda veri toplanmıştır. Ölçüm modelinin geçerlilik ve güvenilirlik } \\
\text { hesaplamaları için SPSS ve Amos programlarından yararlanılmıştır. Daha sonra, her risk unsuru için } \\
\text { olasılık, etki ve önem puanları hesaplanarak riskler ve risk grupları sıralanmıştır. }\end{array}$} \\
\hline Risk & \\
\hline & \\
\hline Risk değerlendirme & \\
\hline Tedarik zinciri risk yönetimi & \\
\hline & \\
\hline & \\
\hline Gönderilme Tarihi 31 Mart & \\
\hline 2020 & \\
\hline $\begin{array}{l}\text { Revizyon Tarihi } 16 \text { Haziran } \\
2020\end{array}$ & \\
\hline Kabul Tarihi 20 Haziran 2020 & $\begin{array}{l}\text { Bulgular - Elde edilen veriler doğrultusunda, işletmelerin tedarik zincirinde karşılaşacağı riskler ve } \\
\text { risk grupları olasılık, etki ve bu iki değerin çarpımından oluşan önem puanları esas alınarak bir } \\
\text { değerlendirmeye tabi tutulmuştur. Talep kaynaklı risk faktörleri ve çevresel risk faktörleri ilk iki } \\
\text { sırayı paylaşan risk grupları olmuştur. Talep kaynaklı risk faktörlerinden alacak riski hem olasılık } \\
\text { hem etki hem de önem puanı için ilk beş sıranın içinde yer almıştır. Olasılık açısından }\end{array}$ \\
\hline Makale Kategorisi: & beklenmedik/geçici müşteriler riski, etki açısından üretimin durması riski ve önem puanı için de \\
\hline Araştırma Makalesi & devlet düzenlemeleri ve kanunlardaki belirsizlik riski ilk sırada bulunmaktadır. \\
\hline
\end{tabular}

Tartışma - Tedarik zinciri risklerinin tanımlanarak gruplandırılması, ardından önem puanlarına göre önceliklendirilmesi tedarik zinciri yöneticileri ve üst yönetimin öncelikli riskleri ele alarak planlar ve yönetim teknikleri geliştirebilmesi açısından önemlidir. Yapılan çalışmalar sıklıkla yüksek olasılık ve düşük etki değerlerine tek başına odaklanmakta, yeterli veri olmadığı gerekçesiyle bu durumun tersini dikkate almamaktadır. Ancak, önem puanı açısından her iki durum da benzer önem değerlerine sahip olacaklardır. Bu yüzden, işletmelerin salt olasılık veya etki değerine odaklanması yerine, bir takım tahmin yöntemlerini kullanarak gerçeğe yakın olasılık ve etki değerleri ile önem puanı hesaplaması ve önem puanları üzerinden risklerin önceliklendirerek yönetim teknikleri geliştirmesi daha uygun olacaktır. Bu çalışmanın, tedarik zinciri risklerini tanımlayıp gruplandırarak, olasılık, etki ve önem puanlarını ile bir sıralama yaparak tedarik zinciri yönetimi ve risk yönetimi literatürüne katkı yaptığı düşünülmektedir.

\begin{tabular}{|c|c|}
\hline ARTICLE INFO & ABSTRACT \\
\hline $\begin{array}{l}\text { Keywords: } \\
\text { Risk } \\
\text { Risk evaluation } \\
\text { Supply chain risk } \\
\text { management }\end{array}$ & $\begin{array}{l}\text { Purpose - Defining, classifying and prioritizing risks within the scope of supply chain risk } \\
\text { management is an important issue in terms of both supply chain and business performance. From } \\
\text { this point of view, the study aims to offer a road map for the companies which includes identification } \\
\text { the risks that companies operating in the manufacturing sector may encounter in their supply chains, } \\
\text { calculation of risk points consisting of probability and impact values of identified risks and } \\
\text { prioritization of risks. }\end{array}$ \\
\hline $\begin{array}{l}\text { Received } 31 \text { March } 2020 \\
\text { Revised } 16 \text { June } 2020 \\
\text { Accepted } 20 \text { June } 2020\end{array}$ & $\begin{array}{l}\text { Design/methodology/approach - The sample of the study consists of } 97 \text { enterprises that operate in } \\
\text { Kocaeli region and continue their production activities in various sectors. Using the survey method, } \\
\text { data were collected on the probability and impact of the risks that these enterprises may encounter } \\
\text { in their supply chains. SPSS and Amos programs were used for the validity and reliability } \\
\text { calculations of the measurement model. Risks and risk groups are listed by calculating probability, } \\
\text { impact and significance scores for each risk element. }\end{array}$ \\
\hline
\end{tabular}

\section{Önerilen Atıf/Suggested Citation}

Tepe Küçükoğlu, M. (2020) Tedarik Zincirinde Risk Değerlendirme: Risklerin Tanımlanması, Gruplandırılması ve Önceliklendirilmesi Üzerine Bir Çalışma, İşletme Araştırmaları Dergisi, 12 (2), 2126-2141. 
Article Classification:

Research Article

\begin{abstract}
Findings - Based on the data obtained, the risks and risk groups that companies will experience in the supply chain have been evaluated based on probability, impact, and the importance score, which is the product of these two values. Accordingly, risk factors originating from demand and external environment are the risk groups that share the first two places. The demand driven risk factors was in the top five among probability, impact and importance score. In terms of probability, the risk of unexpected / temporary customers, in terms of impact, the risk of production breakdown and regarding importance the risk of uncertainty in government regulations and laws are in the first place.

Discussion - It is important to define and group supply chain risks and then prioritize them according to their importance points, so that supply chain managers and senior management can develop plans and management techniques by addressing risk priority. The studies often focus on high probability and low impact values alone and do not take the opposite into account because there is not enough data. However, both cases will have similar significance values in terms of importance score. Therefore, instead of focusing on mere probability or impact value, it would be more appropriate for companies to calculate importance score using realistic estimation methods and develop management techniques by prioritizing risks over importance scores. This study contributes to the supply chain management and risk management literature by identifying and grouping supply chain risks, ranking them with probability, impact and importance scores.
\end{abstract}

\section{GíRiş}

Tedarik zinciri yönetimi, bugünün rekabetçi küresel çevresinde her türlü işletme için başarının anahtar süreçlerinden biri olmasının yanında, örgütsel verimlilik ile karlılığın arttırılmasındaki rekabetçi stratejinin ana bileşenlerinden biridir (Gunasekaran, Patel, \& McGaughey, 2004: 333). Günümüzde, tedarik zincirinin önemi artmış, işletmelerin başarısı içerisinde bulundukları tedarik zincirinin başarısına bağlı hale gelmiştir (Özgüner \& Özgüner, 2019: 67).

İşletmelerin mal veya hizmet üretim süreçlerini desteklemek üzere oluşturdukları yapı (Keskin, 2015) olan tedarik zinciri yönetimi, müşterinin taleplerini yerine getirmek için doğrudan veya dolaylı bir araya gelmiş tüm tarafları içermektedir (Chopra \& Meindl, 2004). Tedarikçiler, üreticiler, depolar, perakendeciler ve müşterilerden oluşan bu entegre sistem sayesinde ürünler, maliyetleri en aza indirmek ve hizmetleri en üst düzeye çıkarmak için doğru miktarlarda, yerlerde ve zamanda sistem genelinde üretilip dağıtılabilmektedirler (Faizal \& Palaniappan, 2014: 20). Literatürdeki çeşitli yazarların tanımlarından yola çıarak Tang (2006: 453)’ın oluşturduğu Tedarik Zinciri Yönetimi tanımı ise şu şeklidedir, "Tedarik zinciri yönetimi, tüketiciler için ürün veya hizmet üretmeyi ve sunmayı amaçlayan ve tedarikçiler, üreticiler, lojistik sağlayıcılar, toptancılar, distribütörler ve perakendecilerden oluşan organizasyon ağı aracılığıyla malzeme, bilgi ve finansal akışların yönetimi olarak tanımlanır. Söz konusu organizasyon ağı içerisindeki pazarlama, satış, üretim, ürün tasarımı, tedarik, lojistik, finans ve bilgi teknolojisi gibi farkl fonksiyonlar arasındaki süreçlerin ve faaliyetlerin koordinasyonunu ve iş birliğini içerir."

Değer zinciri veya talep zinciri olarak da adlandırılan bu yapıda zincire dahil olan her işletmenin ilişkisi stratejik bir seçimdir (Bowersox, Closs, \& Cooper, 2002). Bu seçim, müşteri ve diğer paydaşlar için değer katan ürün, hizmet ve bilgi sağlamak amacıyla son kullanıcı ile ilk tedarikçi arasındaki ana iş süreçlerinin entegrasyonunu gerektirir (Lambert, Cooper, \& Pagh, 1998). İşletmelerin müşterilerine, rakiplerine nazaran daha iyi ürün ve hizmetleri, daha düşük maliyetle ve daha hızlı biçimde sunmalarına yardımcı olarak rekabette öne geçmelerini sağlayacak önemli bir yönetim sürecidir (Demirci Orel \& Akkan, 2018: 84). Etkin bir tedarik zinciri, müşteri ihtiyaçlarını zamanında karşılayarak iş performansını geliştirmeye imkan sağlamaktadır (Punniyamoorthy, Thamaraiselvan, \& Manikandan, 2013: 79). Başarılı bir şekilde yönetilen tedarik zincirleri hem lojistik performansı hem de işletme performansı açısından büyük bir öneme sahiptir (Özgüner \& Özgüner, 2019: 67).

Maliyet baskısı, üretkenliği arttırmak, gelişmekte olan pazarlardaki talepleri karşılamak ve rekabetçi avantajlar elde etmek amacıyla işletmeler küresel ölçekte dış kaynaklardan yararlanma stratejilerine yönelmekte, bu durum da tedarik zinciri ağlarının genişlemesine neden olmaktadır. Böylece, sistemdeki bağlantı noktalarının sayısı da artmaktadır (Faizal \& Palaniappan, 2014: 20; O. Tang \& Nurmaya Musa, 2010: 109). Tedarik zincirinin karmaşık bir hal alması beraberinde katlanmak durumunda olduğu riskleri de arttırmaktadır. Öyle ki, mevcut tedarik zincirleri, artan ağ karmaşıklığı, tedarik zincirini oluşturan farklı işletmeler arasında daha fazla etkileşim, dış tedarikçilere daha fazla bağımlılık, daha kısa ürün yaşam 
döngüleri ve dinamik çevre nedeniyle aksamalara karşı daha hassastır (Punniyamoorthy vd., 2013: 80). Bir tedarik zincirindeki artan karmaşıklık sistemin şeffaflığını engelleyerek süreç üzerindeki kontrolünü azaltmaktadır (Faizal \& Palaniappan, 2014: 19). Diğer taraftan, tedarik zincirindeki işletme sayısının artarak zincirin karmaşık bir yapıya bürünmesi, tedarik zincirlerini daha hantal yapılar haline getirmiştir. Bununla birlikte, diş çevredeki değişime adaptasyon kabiliyetinin azalması aksaklıklara karşı daha kırılgan bir yapıya dönüşmesinin bir başka nedenidir (Tang \& Tomlin, 2008: 12). Özellikle son zamanlarda karşı karşıya kalınan politik ve çevresel tehditler gerek hammadde tedariki, gerekse üretilen mal ve hizmetlerin pazarlara ulaştırılması konusunda problemleri de beraberinde getirmektedir (Özgüner \& Özgüner, 2019: 68). Bu sorunlar tedarik zincirinin performansının azalmasının yanı sıra, finansal kayıplara, olumsuz bir şirket imajına ve talep kaybına yol açabilmektedir (Jüttner, Peck, \& Christopher, 2003: 197). Tedarik zincirindeki aksaklıkların olumsuz sonuçlarını azaltmak ve kontrol altına almak ve tedarik zincirinin risklere karşı kırılganlığını azaltmak için, Tedarik Zinciri Risk Yönetimi bir disiplin olarak önem kazanmaya devam etmekte ve bu alandaki araştırmalar hızla artmaktadır (Hudnurkar, Deshpande, Rathod, \& Jakhar, 2017: 183).

$\mathrm{Bu}$ çalışmanın amacı, tedarik zinciri içerisinde yer alan risk kategorilerinin neler olduğunu tanımlayarak bu kategorilerde yer alan risk faktörlerini olasılık ve etki değerleri açısından değerlendirmektir. Üretim sektöründe faaliyet gösteren işletmeler ile yapılan araştırma sonucunda elde edilen bulgular sayesinde sektöre özgü bir risk sıralaması yapılması bu çalışmanın esas hedefini oluşturmaktadır. Çalışmanın izleyen bölümlerinde, tedarik zincirinde risk unsuru kavramı açılanarak literatürde yer alan çeşitli risk sınıflandırmalarına yer verilecek, ardından sırasıyla metodoloji, bulgular ve sonuçlar bölümleri yer alacaktır.

\section{TEDARİK ZİNCİRINDE RİSK UNSURU}

Geçmiş yıllarda, işletmeler sadece kendi fabrikalarında üretim yaptıkları, yerel pazarlardan tedarik ettikleri ve doğrudan müşteriye sattıkları için risk daha azdı ve yönetimi de daha kolaydı (Faizal \& Palaniappan, 2014: 20). Küreselleşmenin etkisiyle ticaret hayatında ülkelerin coğrafi sınırlarının neredeyse kalkmış olması işletmeleri birtakım değişimlerle yüzleşmek durumunda bırakmıştır. Artan müşteri beklentileri paralelinde karmaşıklaşan ürünler ve üretim süreçleri, rekabetin, belirsizliklerin, krizlerin ve kayıpların artması, etik değerlerin, yatırımcı güveninin azalması işletmeler açısından risk yönetiminin önemini vurgulayıcı olaylardır.

Hissedarlar şirket değerinin artmasını, müşteriler ürün ve hizmet kalitesini, çalışanlar maaş, iş güvencesi ve iş tatminini, tedarikçiler dürüst ve uzun dönemli bir iş birliğini, kredi verenler kredilerin zamanında ödenmesini, kaynakların rasyonel kullanılmasını, devlet vergilerin tam ve zamanında ödenmesini, hesaplarının şeffaf olmasını ve düzenlemelere uyulmasını bekler. Ancak, işletmeler hedeflerine ulaşmaya ve paydaşlarının beklentilerini karşılamaya çalışırken iç ve dış kaynaklı belirsizlikler ve riskler ile karşı karşıya kalmaktadırlar (Özsoy, 2012: 170). Tedarik zinciri içerisinde herhangi bir malzeme, finansal veya bilgi akışı riski problemlerini beraberinde getirmektedir (Tang \& Nurmaya Musa, 2010: 109).

Sıklıkla belirsizlik kavramı ile aynı anlamda kullanılan risk kavramı, bir iş/işlem dolayısı ile oluşmasını beklediğimiz durumdan sapma olasılığıdır (Özsoy, 2012: 170). Müşteriye ürünün ve ürüne bağlı ek hizmetlerin sunumunu zorlaştıran, bazı durumlarda ise olanaksız hale getiren pek çok risk faktörü bulunmaktadır (Demirci Orel \& Akkan, 2018: 84). İlk tedarikçiden son tüketiciye kadar olan süreçte bilgi ve malzeme akışı ile ilgili her türlü risk tedarik zinciri riski kapsamındadır (Jüttner vd., 2003: 197). Heckman ve arkadaşlarına (2015: 119) göre tedarik zincirinin niteliklerinde, tetikleyici olayların ortaya çıkması ve belirsiz gelişmeler sonucunda, tedarik zincirinin verimlilik ve etkinliğinin hedef değerlerinde oluşan olası kayıplar tedarik zinciri risklerini meydana getirir. Bu riskler; gerek tedarikçiden gerekse sektörün içerisinde bulunduğu genel durumdan kaynaklanan, işletmelerin pazarın istek ve beklentilerini karşılama yeteneğini azaltan veya müşterinin devamlılı̆̆ını tehlikeye atan ve sonucunda birtakım mali kayıplar doğuran risklerdir (Zsidisin \& Wagner, 2008: 401). İşletmelerin geçmiş yıllarda yaşadıkları çeşitli olaylar incelendiğinde tedarik zincirinde ürün, bilgi veya hizmet akışını sekteye uğratacak her çeşit olayı kapsayan tedarik zinciri risklerinin yönetilmesinin zorunlu hale geldiği görülmektedir (Demirci Orel \& Akkan, 2018: 87).

Araştırmacılara göre tedarik zinciri risklerini tamamen ortadan kaldırma hedefi gerçekçi olmamakla birlikte zararlı bir olayın olasılığını azaltmak gerçekleştirilebilir bir hedeftir. Bu nedenle, tedarik zinciri risk yönetimi, zarar verici tedarik faaliyetlerinin ortaya çıkma olasılığını ve/veya firma üzerindeki etkisini azaltan satın alma çabalarından oluşmaktadır (Zsidisin \& Ellram, 2003: 15). Bu doğrultuda, bir taraftan riskleri yönetmek diğer taraftan da karlılığı ve sürekliliği sağlamak tedarik zinciri ortakları arasındaki koordinasyon veya işbirliği 
yoluyla mümkündür (Tang, 2006: 453). İşletmeler tedarik zinciri risklerini azaltmak için etkili araçlar tasarlamadan önce, yöneticiler risk kategorilerinin evrenini ve onları yönlendiren olayları ve koşulları anlamalıdır. Ardından, bu önemli riskler hakkında net ve özel bilgilerle donatılmış işletmeler, en etkili olabilecek azaltma stratejilerini seçmeye ve uyarlamaya devam edebilirler (Chopra \& Sodhi, 2004: 54).

Günümüzde, tedarik zincirindeki riskleri yönetmek daha zordur, çünkü tek başına gibi görünen riskler genellikle birbirine bağlıdır ve bir riski azaltan eylemler diğerini daha kötü hale getirebilir (Chopra \& Sodhi, 2004: 54). Bu nedenle, herhangi bir risk yönetim stratejisi tedarik zincirindeki bu risk etkileşimi sebebiyle entegre bir risk yönetim yaklaşımını gerektirir (Punniyamoorthy vd., 2013: 80). Bu bağlamda bilinen risk yönetiminden kurumsal risk yönetimine geçişte olduğu gibi tedarik zinciri risk yönetiminde de risklerin bağımsız ve ayrı ayrı ele alınması yerine sistem düşüncesi ve bütünleşik bir bakış açısıyla değerlendirilmesi gerekmektedir.

İşletmelerin sürdürülebilir büyüme amacına ulaşmasında karşı karşıya kalacağı risklerin tanımlanarak, değerlendirilmesi ve yönetilmesi oldukça önemli bir konudur. Bu nedenle, işletmeler risklerini stratejik bir unsur olarak görmekte ve sistematik bir şekilde yöneterek rekabet avantajı sağlamayı öngörmektedirler (Walker, Shenkir, \& Barton, 2002).

Lojistik yazınında tedarik zinciri riskleri üzerinde yapılan çalışmaların son yıllarda arttı̆̆ı görülmektedir. Bunlar arasında, risklerin performans üzerindeki etkisinin incelendiği (Özgüner \& Özgüner, 2019; Yolaç, Tuzcuoğlu, \& Şahin, 2019), tedarik zinciri kaynaklı risklerin tanımlanarak, bir risk yönetim sisteminin oluşturulduğu (Blos, Quaddus, Wee, \& Watanabe, 2009), tedarikçi ve parçaya özgü risklerinin ölçümü, izlenmesi ve analizi için tedarikçi risk değerlendirme metodolojisinin geliştirildiği (Blackhurst, Scheibe, \& Johnson, 2008), ortak risk profiline sahip sektörler için risk değerlendirme ve önceliklendirme aracının geliştirilerek test edildiği (Punniyamoorthy vd., 2013; Wang, Jie, \& Abareshi, 2014) çalışmalar yer almaktadır.

Teorik çalışmalara bakıldığında ise; gerek yasal düzenlemeler gerekse çevre koşullarındaki değişimin etkisiyle artan öneminin değerlendirildiği (Ceritoğlu, 2018), tedarik zinciri risklerinin kökenleri, tedarik zinciri riski ile tedarik zinciri performansı arasındaki ilişkinin kavramsal olarak incelendiği (Demirci Orel \& Akkan, 2018), tedarik zinciri risklerinin sıralanarak bu risklerin azaltılmasında uygulanabilecek stratejilerin açıklandığ1 (Chopra \& Sodhi, 2004), içerik analizi ile tedarik zinciri risk kaynaklarını tanımlanıp sıralandığı (Hudnurkar vd., 2017), tedarik zinciri risk yönetimi alanının gelişim evreleri, riskin nasıl tanımlandığı, kullanılan araştırma yöntemleri, sektöre özgü olarak karşılaşılan riskler ve yönetme biçimleri ile katkıları açısından literatürdeki yayınların incelendiği (Singhal, Agarwal, \& Mittal, 2011) çalışmalar bulunmaktadır.

\subsection{Tedarik Zincirinde Risklerin Sınıflandırılması}

Dünya Ekonomik Forumu'nun 2019 yılında 14.'sünü yayınladığı Küresel Risk Raporu'na göre dünyada olma olasılığı en yüksek riskler önem düzeyine, etki düzeyine ve kategorisine göre sınıflandırılmıştır. Bu riskler aşağıdaki Tablo 1'de yer almaktadır.

Tablo 1. Dünya' daki olasılık ve etki değerine göre ilk 10 risk türü

\begin{tabular}{|l|l|}
\hline Olasılık düzeyine göre ilk 10 risk & Etki düzeyine göre ilk 10 risk \\
\hline 1.Aşırı iklim olayları (Ç) & 1.Kitle imha silahlarının yapacağı yıkım (J) \\
\hline $\begin{array}{l}\text { 2.İklim değişikliğini azaltma ve iklim değişikliğine } \\
\text { uyum konusunda yaşanacak başarısızlık (Ç) }\end{array}$ & $\begin{array}{l}\text { 2.İklim değişikliğini azaltma ve iklim değişikliğine } \\
\text { uyum konusunda yaşanacak başarısızlık (Ç) }\end{array}$ \\
\hline 3.Doğal afetler (Ç) & 3.Aşırı iklim olayları (Ç) \\
\hline 4.Veri dolandırıcllı̆̆/hırsızlığı (T) & 4.Su krizleri (S) \\
\hline 5.Siber saldırılar (T) & 5.Doğal afetler (Ç) \\
\hline 6.İnsan ürünü çevresel felaketler (Ç) & 6.Biyoçeşitliliğin azalması, ekosistemin çöküşü (Ç) \\
\hline 7.Büyük ölçekli istenmeyen göç (S) & 7.Siber saldırılar (T) \\
\hline 8.Biyoçeşitliliğin azalması, ekosistemin çöküşü (Ç) & 8.Kritik bilgi altyapısının bozulması (T) \\
\hline 9.Su krizleri (S) & 9.İnsan ürünü çevresel felaketler (Ç) \\
\hline 10.Genel ekonomideki varlık balonları (E) & 10.Bulaşıcı hastalıkların yayılması (S) \\
\hline Ç: Çevresel risk; T: Teknolojik risk; E: Ekonomik risk, S: Sosyal risk; J: Jeopolitik risk \\
\hline
\end{tabular}

Kaynak: The Global Risks Report 2019: 14th Edition (World Economic Forum, 2019) 
Dünya Ekonomik Forumu'nun gerçekleştirdiği başka bir araştırma da tedarik zinciri ve taşıma riskleri üzerinedir. Günlük periyotlarda tedarik zinciri ve taşıma ağlarında çeşitli aksaklıklar meydana gelmektedir. Bununla birlikte, bazı çevresel faktörler, mevcut ağlardaki açıklarla birleştirildiğinde, yaygın sistemik bozulmalara neden olma potansiyeline sahiptir. Tablo 2'de tedarik zinciri veya ulaştırma ağları üzerinde önemli ve sistemik etkilere neden olma ihtimaline sahip çevresel risk faktörleri sıralanmıştır (World Economic Forum, 2012).

Tablo 2. Küresel tedarik zincirindeki aksamaları tetikleyen çevresel risk faktörleri

\begin{tabular}{|c|c|c|}
\hline Risk türü & Çevresel risk faktörleri & Oranı \\
\hline \multirow[t]{3}{*}{ Çevresel risk grubu } & Doğal afetler & $\% 59$ \\
\hline & Kötü hava şartları & $\% 30$ \\
\hline & Salginlar & $\% 11$ \\
\hline \multirow[t]{7}{*}{ Jeopolitik risk grubu } & Jeopolitik çatışma ve siyasi huzursuzluk & $\% 46$ \\
\hline & İhracat / ithalat kısitlamaları & $\% 33$ \\
\hline & Terör & $\% 32$ \\
\hline & Yolsuzluk & $\% 17$ \\
\hline & Yasadışı ticaret ve organize suç & $\% 15$ \\
\hline & Deniz korsanlı̆̆1 & $\% 9$ \\
\hline & Nükleer / biyolojik / kimyasal silahlar & $\% 6$ \\
\hline \multirow[t]{7}{*}{ Ekonomik risk grubu } & Ekonomik ani talep şokları & $\% 44$ \\
\hline & Emtia fiyatlarında aşırı oynaklık & $\% 30$ \\
\hline & Sinır gecikmeleri & $\% 26$ \\
\hline & Döviz dalgalanmaları & $\% 26$ \\
\hline & Global enerji sıkıntısı & $\% 19$ \\
\hline & Mülkiyet / yatırım kısıtlamaları & $\% 17$ \\
\hline & İşgücü yetersizliği & $\% 17$ \\
\hline \multirow[t]{2}{*}{ Teknolojik risk grubu } & Teknolojik bilgi ve iletişim kesintileri & $\% 30$ \\
\hline & Ulaştırma altyapısı başarısızlıkları & $\% 6$ \\
\hline
\end{tabular}

Kaynak: New Models for Addressing Supply Chain and Transport Risk (World Economic Forum, 2012)

Bir tedarik zincirinde işletmenin içinde ve dışında bulunan faktörlere ilişkin çeşitli risk kaynaklarının tanımlanması riski anlamak ve yönetmek için önemlidir (Punniyamoorthy vd., 2013: 95). Risklerin tanımlanması tedarik zinciri risk yönetimi sürecinin önemli bir ilk adımıdır. Riskler tanımlandıktan sonra, risk yöneticilerinin risk kategorilerinin evrenini ve riskleri yönlendiren olayları ve koşulları anlamalarını sağlamak için riskleri farklı kategorilere ayırmak önemlidir. Bu anlayış daha sonra en etkili olması muhtemel olan farklı risk azaltma stratejilerinin seçilmesini ve tasarlanmasını kolaylaştıracaktır (Chopra \& Sodhi, 2004: 54). Tedarik zincirinde karşılaşılan riskler literatürde farklı gruplandırmalarla sıralanmaktadır. Bu sınıflandırma risk türleri veya risk kaynakları adı ile yer almaktadır. Bir tedarik zincirindeki kuruluşlar arasında risk tanımlaması ve değerlendirmesi için ortak bir kelime haznesi oluşturmak ve bilinen tedarik zinciri riskleri için risk azaltma stratejilerini standartlaştırmak için evrensel olarak kabul edilmiş bir tedarik zinciri riskleri sınıflamasına sahip olmak önemlidir (Hudnurkar vd., 2017: 185).

Tedarik zinciri yönetimi literatüründe risk kaynaklarını tanımlayıp sınıflandıran kapsamlı çalışmalar bulunmaktadır. Bir bakış açısı sunması için literatürde yer alan çeşitli tedarik zinciri risk sınıflandırmaları Tablo 3'te gösterilmektedir. 
Tablo 3. Tedarik zinciri risk sinıflandırmaları

\begin{tabular}{|c|c|}
\hline Risk türleri sınıflandırması & Yazar \\
\hline $\begin{array}{l}\text { Finansal risk, organizasyonel risk, tedarik riski, üretim riski, müşteri ve pazar } \\
\text { riski, lojistik ve ulaştırma riski, teknoloji riski, çevresel risk, jeopolitik risk, } \\
\text { yasal ve bürokratik risk, sektöre özgü risk, tedarik zinciri yapısıyla alakalı risk }\end{array}$ & $\begin{array}{l}\text { (Er Kara \& Oktay Firat, } \\
\text { 2017) }\end{array}$ \\
\hline $\begin{array}{l}\text { Ürün özellikleri, tedarik zinciri yönetimi süreçleri, tedarik zinciri altyapısı, dış } \\
\text { çevre ve insan kaynakları }\end{array}$ & (Hudnurkar vd., 2017) \\
\hline $\begin{array}{l}\text { Operasyonel, altyapı, yasal, kültürel ve sosyal, ekonomik, tedarikçi, depolama, } \\
\text { dağıtım, işçilik, doğal felaketler kaynaklı riskler }\end{array}$ & $\begin{array}{l}\text { (Rogers, Srivastava, } \\
\text { Pawar, \& Shah, 2016) }\end{array}$ \\
\hline $\begin{array}{l}\text { Tedarikçi kaynaklı riskler, üretici kaynaklı riskler, talep kaynaklı riskler, } \\
\text { lojistik kaynaklı riskler, bilgi kaynaklı riskler ve çevresel riskler } \\
\text { İşletme içi, işletme dışı ama tedarik zinciri içerisinde ve tedarik zinciri ağının } \\
\text { dışında }\end{array}$ & $\begin{array}{l}\text { (Punniyamoorthy vd., } \\
\text { 2013) }\end{array}$ \\
\hline $\begin{array}{l}\text { Malzeme akış riskleri (kaynak - tek tedarikçi riski, tedarikçi esnekliği riski, } \\
\text { tedarikçi seçimi, tedarik kalitesi, tedarik kapasitesi, } \\
\text { Üretim - ürün ve süreç tasarım riski, üretim kapasitesi riski, üretim duruşu } \\
\text { Dağıtım - talep dalgalanması / mevsimsellik ve karşılanmayan talep ve fazla } \\
\text { stok dengesi } \\
\text { Bilgi akış riskleri (bilgi doğruluğu, bilgi sistem güvenliği, fikri mülkiyet ve } \\
\text { bilgi dış kaynak riski } \\
\text { Finansal akış riskleri (kur riski, fiyat ve maliyet riski, tedarik zinciri } \\
\text { ortaklarının finansal gücü ve finansal işlemler) }\end{array}$ & (Musa, 2012) \\
\hline $\begin{array}{l}\text { Tedarik kaynaklı riskler, talep kaynaklı riskler, süreç riskleri, çevresel riskler, } \\
\text { lojistik riskleri, katastrofik riskler } \\
\text { İşletme içi, işletme dışı ve ağ içi, ağ dışı }\end{array}$ & (Sharma \& Bhat, 2012) \\
\hline $\begin{array}{l}\text { Tedarikçilerden kaynaklanan riskler, üretici firmaya bağlı riskler, müşteriden } \\
\text { kaynaklanan riskler ve çevresel faktörlerin meydana getirdiği riskler }\end{array}$ & (Büyüközkan, 2008) \\
\hline Tedarik riskleri, faaliyet riskleri ve talep riskleri & (Manuj \& Mentzer, 2008) \\
\hline $\begin{array}{l}\text { Tedarik riski, süreç riski, talep riski, fikri mülkiyet riski, davranışsal riskler ve } \\
\text { politik/sosyal riskler }\end{array}$ & (C. Tang \& Tomlin, 2008) \\
\hline $\begin{array}{l}\text { Aksama riski, gecikme riski, bilgi sistemleri kaynaklı riskler, tahmin riski, fikri } \\
\text { mülkiyet riski, satın alma riski, alacak riski, envanter riski ve kapasite riski } \\
\text { Tedarikçi kaynaklı, işletme kaynaklı veya müşteri kaynaklı }\end{array}$ & (Chopra \& Sodhi, 2004) \\
\hline $\begin{array}{l}\text { İşletmenin içinde, işletmenin dışında ve tedarik zincirinin içinde, tedarik } \\
\text { zinciri ağını dışında }\end{array}$ & (Christopher \& Peck, 2004) \\
\hline
\end{tabular}

Her işletmenin karşı karşıya kaldığı riskler birbirinden farklıdır. İşletmenin faaliyet alanı, bulunduğu ülke, sektörü, müşteri profilleri, tedarik zinciri, çalışanları, iş modeli, teknoloji kullanma yoğunluğu, kullanılan teknolojinin türü, rekabet yapısı gibi birçok faktöre göre değişmektedir (Özsoy, 2012: 176).

Tüm bu sınıflandırmalara ek olarak, söz konusu bir riskin gerçekleşmesi sık veya seyrek olabilir, kısa veya uzun vadeli ve etkilenen kuruluşlar için küçükten çok büyük ölçekliye kadar çeşitli sorunlara neden olabilir. Zincir boyunca basit bir gecikme geçici bir risk yaratabilir, oysa üreticiyi bir fiyat artışına zorlayan tek tedarikçi, uzun vadeli bir riski temsil eder. Bir makine arızası, yedekli kapasiteye sahip bir imalatçı şirket üzerinde nispeten küçük bir etkiye sahip olabilirken, ulaşım yolları üzerindeki bir savaşın bir nakliye şirketi üzerinde büyük bir etkisi olmaktadır (Chopra \& Sodhi, 2004: 54).

Aşağıda bu çalışmada kullanılan ve Punniyamoorthy ve arkadaşlarının (2013: 85) sınıflandırmasında yer alan risk türleri kısaca anlatılmaktadır.

\subsubsection{Tedarikçi kaynaklı riskler}

İşletmeler, tedarik zincirlerinde sayısız risklere maruz kalmaktadır. Tedarik tarafındaki riskler tedarik ürünlerinde, satın almada ve tedarikçi ilişkilerinde bulunur (Sharma \& Bhat, 2012: 354). Tedarikçi kaynaklı risk, üretici işletmenin tedarikçi işletmeleriyle arasında gelişen veya genel tedarikçi piyasasında meydana 
gelen belirsizlikler nedeniyle, işletmenin üretim gereksinimlerini / talep tahminlerini etkin bir şekilde karşılaması için ihtiyaç duydukları malzemeleri teslim edememesiyle ilişkili risk olup girdi riski olarak da adlandırılır. (Ceritoğlu, 2018: 206; Faizal \& Palaniappan, 2014: 20). Tedarikçi kaynaklı risklere örnek olarak kalite problemleri, kritik malzemenin karmaşıklığı, eksik tedarik, esnek olmayan tedarikçi, tedarikçinin sorumluluğunu yerine getirememesi, tedarikçinin finansal problemleri, tek tedarikçi bulundurma, tedarikçideki sık değişimler, tedarik pazarındaki kapasite kısıtları, tedarikte gecikmeler, fikri mülkiyet riskleri, kilit tedarikçinin fiyat indirmemesi, satın alma fiyatlarındaki ani artış, tedarikçilerin etik olmayan uygulamalarının ortaya çıkması olarak sıralanmaktadır (Punniyamoorthy vd., 2013: 82; Sharma \& Bhat, 2012: 356).

\subsection{2.Üretici kaynaklı riskler}

Üretici işletmenin üretim ve lojistik sürecinde hatalı planlama yapması, insan kaynakları ve üretim araçlarındaki beklenmedik sorunlar ile bunların sonucu olarak üretim süre ve kalitesinde meydana gelen değişiklikler, üretimin aksaması veya durmasına neden olan risklerdir (Ceritoğlu, 2018: 210). Üretim sırasında makine arızasının meydana gelmesi, grevler, iş kazaları üreticinin iş süreçleri ile ilgili risk örnekleridir (Sharma \& Bhat, 2012: 356). İç kaliteyi ve kapasiteyi arttırmak için, işletmeler 10 yıldan fazla bir süredir Toplam Kalite Yönetimi, Yalın Üretim ve Altı Sigma gibi programlara yatırım yapmaktadırlar. Bununla birlikte, işletme içi faaliyetler halen etkin kapasite ve kalitede dalgalanmalara neden olabilecek sorunlara karşı hassastır. (Tang \& Tomlin, 2008: 13)

\subsubsection{Talep kaynaklı riskler}

Talep miktarında öngörülemeyen değişimler, üretim miktarlarında ve teslim zamanlarında oluşan dalgalanmalar, beklenmedik sipariş iptalleri, üretici ve tedarikçi işletmeleri zor durumda bırakmaktadır (Büyüközkan, 2008). Dolayısıyla talep riski, hem hacim hem de ürün karmasındaki belirsizlikleri içerir (Tang \& Tomlin, 2008: 13). Değişken talep, tahmin hatası, müşteriden gelen yetersiz veya karmaşık bilgi, kilit müşteri kaybı ve kredi riski talep kaynaklı riskler içerisinde sıralanmaktadır (Sharma \& Bhat, 2012: 356) Talep kaynaklı riskler, rastgele tüketici davranışının belirsizliğinden kaynaklanan risklerdir (Nagurney, Cruz, Dong, \& Zhang, 2005: 120). Bu bağlamda, tahmin kalitesini etkileyen ve bu nedenle tedarik zincirinin yukarı yönlü akışında talep dalgalanmalarında yükselmeye neden olan önemli bir sorun kamçı etkisi olarak adlandırılır. Kamçı etkisinin nedenleri, çarpık bilgi, satış teşviki, toplu sipariş, aşırı tepkiler, gereksiz müdahaleler, ikinci tahmin ve güvensizlik olarak yer almaktadır (Lee, Padmanabhan, \& Wang, 1997: 546).

\subsubsection{Lojistik kaynaklı riskler}

Lojistik aksaklıkları nihai müşteriye olan teslimatı etkilemektedir. Lojistik ve nakliye riskleri, malların depolanması, paketlenmesi ve teslimatı ile ilgili riskleri kapsar. Lojistik performansının düşük olmasının sebepleri arasında lojistik sektöründeki profesyonellik eksikliği, belirsiz trafik koşulları, trafik sıkışıklığı ve zayıf altyapı nedeniyle liman ve gümrük kapılarındaki aksaklıklar, engellenen rotalar, uçak uçuşlarının durdurulması, otoyol gişelerindeki yanlış uygulamalar yer almaktadır (Er Kara \& Oktay Fırat, 2017: 48; Sharma \& Bhat, 2012: 355).

\subsubsection{Bilgi kaynaklı riskler}

Bilgi kaynaklı riskler; bilgi sistemleri, iletişim sistemleri, teknoloji ile ilgili gelişmeleri kapsamaktadır. Bilgi sistemleri için bilginin bulunamaması, bilginin gecikmesi, bilgi altyapısının bozulması, bilgi paylaşım problemleri, bilgi sisteminin güvenliği, gizlilik riski, siber saldırılar, sistem uygulama ve yönetim sorunları, sistem arızaları başlıca risk konularıdır. İletişim sistemleri ile ilgili riskler iletişim sorunları, kararsız ve verimsiz iletişim ağları ve altyapısı ile iletişim standartlarındaki farklılıktan kaynaklanmaktadır. Teknoloji ile ilgili gelişmelerden kaynaklanan riskler ise, teknolojideki değişiklikleri, çığır açan bilimsel buluşları, hızlı teknolojik gelişmeleri, teknoloji uyumsuzluklarını ve sektördeki teknolojik yenilikleri ifade etmektedir (Er Kara \& Oktay Furat, 2017: 48; Punniyamoorthy vd., 2013: 83).

\subsection{6.Çevresel riskler}

Bu risk türü işletme dışı faktörlerden kaynaklanan ve kontrol edilemeyen olayları içerir. Tedarik zincirinden ve çevresel etkileşimlerden kaynaklanan belirsizliklerden oluşur. Doğal afetler, savaş ve ya terörist faaliyetler, kural ve düzenlemelerdeki değişiklikler çevresel risklere örnektir (Faizal \& Palaniappan, 2014: 21). İdari, yasal 
ve düzenleyici kurumlar gibi otoriteler, tedarik zincirinin kurulmasında ve işletilmesinde önemli bir belirsizlik faktörüdür. Gümrük ve ticaret düzenlemesi gibi idari engeller, tedarik zincirlerinin operasyonel performansını kısıtlayabilmektedir. Yasal değişiklikler genellikle ani ve tahmin edilmesi zor durumlar içermektedir. Yeni çevreci düzenlemeler ile tersine lojistik sistemlere yatırım, lojistiğin koşullarının değişmesi tedarik zincirinin karmaşıklığını arttırmaktadır (Sharma \& Bhat, 2012: 355). Çevresel risklere en güncel örnek ise salgın hastalıklar olarak verilebilir. Dünya çapında etkili olan Koronavirüs (COVID-19) tehdidi 2020 yılında en önemli çevresel risk faktörünü oluşturmuştur. Virüsün yayılımını önlemek amacıyla alınan tedbirler kapsamında, sınırların kapanması, ulaşımın aksaması, üretim duruşları ve diğer karantina önlemleri tedarik zincirlerinin durma noktasına gelmesine neden olmuştur.

\section{ARAŞTIRMA METODOLOJİSI}

\subsection{Araştırmanın Amacı}

Risk değerlendirmesinin amacı, değer zincirinde hangi alanların ve faaliyetlerin tehlikelere karşı daha duyarlı olduğunu göstermektir. Risk yönetimi ise, risklerle başa çıkmak için tasarlanmış geniş bir planlama ve karar verme faaliyetidir. Risk türlerini, ortaya çıkma ihtimallerini ve etkilerini anlamak, işletmelerin etkili risk yönetimi stratejileri geliştirmeleri için bir başlangıç noktasıdır (Faizal \& Palaniappan, 2014: 22). Bu doğrultuda işletmelerin tedarik zincirinde karşı karşıya kalabileceği risk türlerinin neler olduğu, bu risklerin gerçekleşme olasılıklarının ve meydana getireceği etkilerinin değerlendirilerek her risk türünün önem puanının hesaplanması ve öncelikli risklerin ortaya çıkarılması bu çalışmanın esas amacını oluşturmaktadır. Bu amaçla aşağıdaki soruların cevapları araştırılmaktadır.

1. Tedarik zinciri yönetiminde karşılaşılan risk grupları ve bu gruplarda yer alan riskler nelerdir? (Tanımlama ve siniflandirma)

2. Tedarik zincirindeki risk grupları incelendiğinde toplam risk üzerinde bu grupların payı nedir? (Değerlendirme)

3. Söz konusu riskler olasılık ve etki değerleri üzerinden hesaplanan bir risk puanı ile değerlendirildiğinde öncelikli riskler hangileridir? (Önceliklendirme)

4. Sektör, işletme faaliyet yılı ve büyüklügü açısından risk gruplarının önem derecelerine göre farklılık var midır? (Farklılık analizi)

\subsection{Araştırmanın Yöntemi}

Tedarik zincirinde karşılaşılan risklerle ilgili olarak literatürde birçok farklı sınıflandırma yapılmıştır. Bu çalışmada Punniyamoorthy ve arkadaşlarının (2013: 85) önermiş olduğu risk sınıflandırması temel alınmıştır. Bu sinıflandırmaya göre bir tedarik zincirinde karşılaşılabilecek temel risk türleri; tedarikçi kaynaklı riskler, üretici kaynaklı riskler, talep kaynaklı riskler, lojistik kaynaklı riskler, bilgi kaynaklı riskler ve çevresel riskler olarak tanımlanmıştır.

Kullanılan anket formunda, tedarikçi kaynaklı risk faktörleri 12 ifadeden, üretici kaynaklı risk faktörleri 11 ifadeden, talep kaynaklı risk faktörleri 6 ifadeden, lojistik kaynaklı risk faktörleri 7 ifadeden, bilgi kaynaklı risk faktörleri 4 ifadeden ve çevresel riskler de 6 ifadeden oluşmaktadır. Geliştirilen bu risk ölçeğinde meydana gelme olasılığı için 5li Likert ölçeği kullanılmıştır. Ölçek ifadeleri anket katılımcıları tarafından olasılık açısından değerlendirilirken ilgili riskin meydana gelme frekansı yılda bir ise çok küçük, üç ayda bir ise küçük, ayda bir ise orta, haftada bir ise yüksek ve her gün ise çok yüksek ifadesi kullanılmış; çok küçük ifadesi 1 ve çok yüksek ifadesi 5 değeri ile temsil edilmiştir. İşletmeye olan etki açısından değerlendirilirken, etkisi çok düşük ise çok hafif, sınırlı etkisi varsa hafif, orta düzeyde etkisi varsa orta, ciddi/kalıcı etkisi varsa ciddi, işletmenin kapanmasına/iflasına neden olan bir etki söz konusu ise çok ciddi ifadesi kullanılarak; çok hafif ifadesi 1 ve çok ciddi ifadesi 5 değeri ile temsil edilmiştir. Kullanılan anket formu çalışmanın ekler kısmında yer almaktadır.

Öncelikle kullanılan ölçek için güvenilirlik ve geçerlilik analizleri yapılmıştır. Daha sonra, her risk unsuru için olasılık, etki ve önem puanları hesaplanarak riskler ve risk grupları sıralanmıştır.

Kocaeli sınırları içinde üretim sektöründe çeşitli alanlarda faaliyet gösteren 97 işletme bu çalışmanın örneklemini oluşturmaktadır. Ankete katılan işletmelerin başlıca sektörleri gıda, tekstil, metal, otomotiv, elektronik, ilaç, inşaat olarak sıralanmaktadır. Anket çalışması 2019 yılının Ekim ayında başlamış, Aralık ayına kadar sürmüştür. 


\subsection{Araştırmanın Bulguları}

Araştırma için kullanılan anket sorularının ilk bölümünde işletmenin sektörü, büyüklüğü ve faaliyet süresi olmak üzere üç konuda tanımlayıcı bilgiler istenmiştir. Elde edilen veriler doğrultusunda; katılan işletmelerin sektörlerinin ağırlıklı olarak gıda (\%34), tekstil (\%13), metal (\%13), otomotiv (\%12) ve diğer (\%27) sektörlerden oluştuğu görülmektedir. Bu işletmelerin \%45'i küçük, \%20'si orta ve yine \%20'si büyük, \%15'i de çok büyük işletme kategorisinde bulunmaktadır. Son olarak işletmelerin \%43'ü 25 yıl ve üzeri, \%8'i 20-24 yıl, \%7'si 15-19 yıl, \%10’u 10-14 yıl, \%17'si 5-9 yıl ve \%15'i de 1-4 yıl aralığında faaliyet göstermektedir.

Kullanılan ölçüm modeli güvenilirlik ve geçerlilik açısından test edilmiştir. Güvenilirlik değeri için Cronbach's alpha katsayısı kullanılmıştır. Tüm risk gruplarının yeterli güvenilirlik değerine sahip olduğu görülmüştür. $(\alpha>0,70)$ Ölçek geçerliliği için de doğrulayıcı faktör analizi gerçekleştirilmiştir. Doğrulayıcı faktör analizi sonucu bulunan uyum iyiliği değerleri iyi veya kabul edilebilir uyum değerlerine sahiptir. Bulunan değerler ve toplam risk modeli faktör yükleri tabloda gösterilmektedir.

Tablo 4. Tedarik zinciri riskleri ölçüm modelinin geçerlilik ve güvenilirlik analizi sonuçları

\begin{tabular}{|c|c|c|c|c|c|c|c|}
\hline & Risk grupları & $\begin{array}{l}\text { Madde } \\
\text { sayıs1 }\end{array}$ & $\begin{array}{l}\text { Cronbach's } \\
\text { alpha }\end{array}$ & CMIN/DF & GFI & CFI & RMSEA \\
\hline \multirow{6}{*}{ 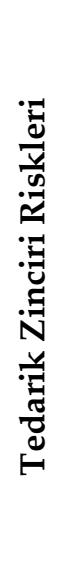 } & $\begin{array}{l}\text { Tedarikçi kaynaklı risk } \\
\text { faktörleri }\end{array}$ & 12 & 0,922 & 1,355 & 0,910 & 0,976 & 0,061 \\
\hline & $\begin{array}{l}\text { Üretici kaynaklı risk } \\
\text { faktörleri }\end{array}$ & 11 & 0,932 & 1,529 & 0,900 & 0,966 & 0,074 \\
\hline & $\begin{array}{l}\text { Talep kaynaklı risk } \\
\text { faktörleri }\end{array}$ & 6 & 0,827 & 1,097 & 0,972 & 0,996 & 0,032 \\
\hline & $\begin{array}{l}\text { Lojistik kaynaklı risk } \\
\text { faktörleri }\end{array}$ & 7 & 0,911 & 1,572 & 0,955 & 0,987 & 0,077 \\
\hline & $\begin{array}{l}\text { Bilgi kaynaklı risk } \\
\text { faktörleri }\end{array}$ & 4 & 0,918 & 2,838 & 0,974 & 0,987 & 0,038 \\
\hline & $\begin{array}{l}\text { Çevresel kaynaklı risk } \\
\text { faktörleri }\end{array}$ & 6 & 0,865 & 1,241 & 0,976 & 0,994 & 0,050 \\
\hline
\end{tabular}

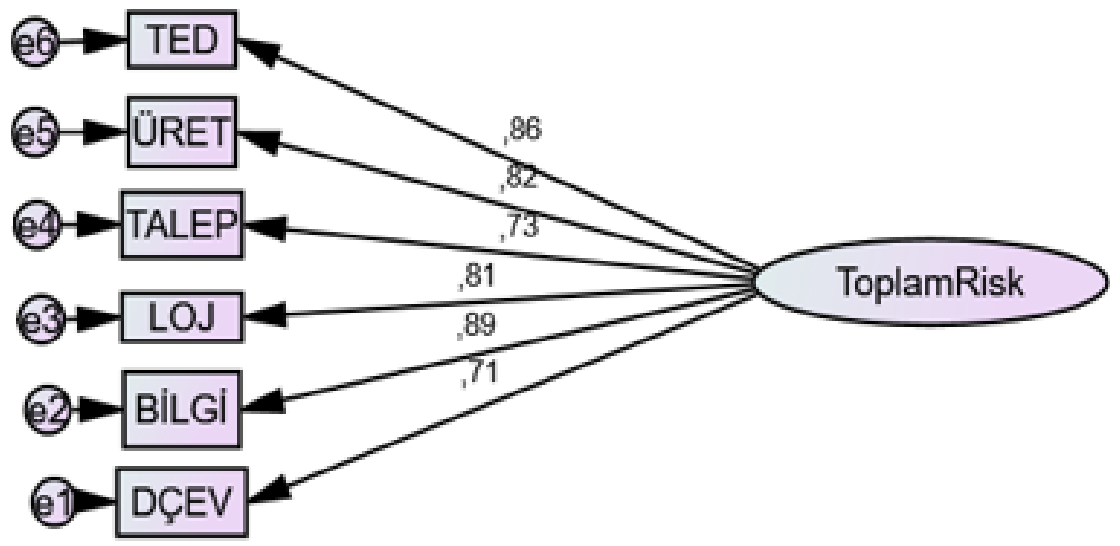

CMIN/DF:1,592 GFI:0,958 CFI:0,988 RMSEA:0,079

Tedarik zinciri içerisinde karşılaşılan riskler ve risk gruplarının değerlendirildiği anket verileri;

- Olasılık değerleri açısından tüm risk maddeleri ve risk gruplarının sıralanması,

- Etki değerleri açısından tüm risk maddeleri ve risk gruplarının sıralanması,

- Önem puanları (önem puanı = olasılık x etki) açısından tüm risk maddeleri ve risk gruplarının sıralanması şeklinde incelenmiştir.

Olasılık değerleri kullanılarak risk gruplarının sıralandığı ve tüm maddelerin yine olasılık değerlerine göre yer aldığı grafik görünümü aşağıdaki Tablo 5'te yer almaktadır. İlk sırada talep kaynaklı risk faktörlerinin olasılık açısından en büyük değere sahip olduğu, bilgi kaynaklı faktörlerin de son sırada yer aldığı 
görülmektedir. Tüm maddeler incelendiğinde ilk beş sırada talep ve çevresel faktörlere ait maddeler olduğu, sırasıyla beklenmedik/geçici müşteriler (TA1), alacak riski (TA4), devlet düzenlemeleri ve kanunlardaki belirsizlik (DÇ3), makroekonomik belirsizlik (DÇ2) ile müşteri tercihlerinde değişimin (TA5) bulunduğu tespit edilmiştir.

Tablo 5. Olasılık değerine göre risk grupları ve risk maddeleri sıralaması

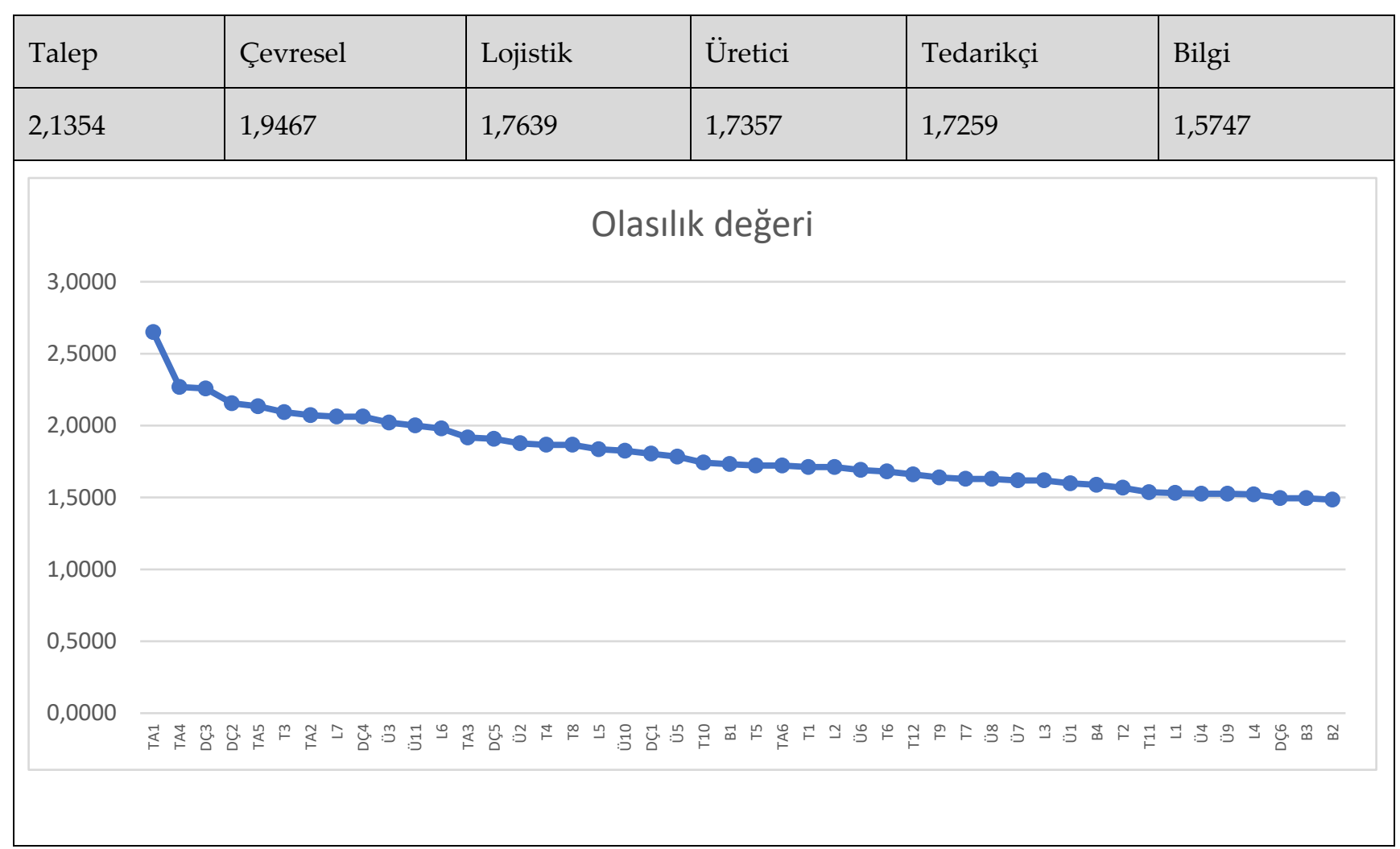

Etki değerlerine için risk grupları incelendiğinde çevresel risk faktörlerinin ilk sıradaki risk grubu olduğu bulunmuştur. Son sırada ise tedarikçi kaynaklı risk faktörleri yer almaktadır. Risk maddelerine bakıldığında, üretimin durması (Ü1), savaş, terörizm, doğal afetler, grev, ayaklanma gibi elde olmayan etmenler (DÇ6), itibar riski (TA6), kalifiye gücünün olmayışı (DÇ5) ve alacak riski (TA4) şeklinde karşımıza çıkmaktadır. Tablo $6^{\prime}$ da risk grupları ve risk maddelerinin sıralaması görülmektedir.

Tablo 6. Etki değerine göre risk grupları ve risk maddeleri sıralaması

\begin{tabular}{|c|c|c|c|c|c|}
\hline Çevresel & Talep & Bilgi & Üretici & Lojistik & Tedarikçi \\
\hline 3,0601 & 2,9124 & 2,8247 & 2,7488 & 2,6406 & 2,6271 \\
\hline \multicolumn{6}{|c|}{ Etki değeri } \\
\hline \multicolumn{6}{|l|}{5,0000} \\
\hline \multicolumn{6}{|c|}{ 4,0000 } \\
\hline \multicolumn{6}{|c|}{ 3,0000 } \\
\hline \multicolumn{6}{|c|}{$\begin{array}{l}2,0000 \\
1,0000 \\
\end{array}$} \\
\hline 0,0000 & \multicolumn{5}{|c|}{ 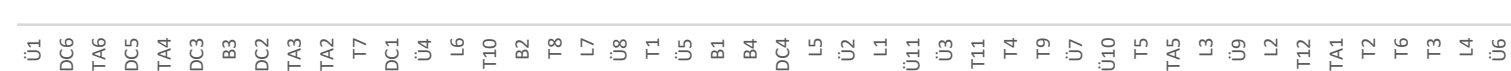 } \\
\hline
\end{tabular}


Önem puanı, her bir maddenin olasılık ve etki değeri çarpılarak hesaplanır. Bu değere risk puanı da denilmektedir (Yazıcı, 2018: 24). Önem puanı açısından risk gruplarının öncelik sırası ve tüm maddelerin önem skorlarına göre sıralandığı grafik aşağıdaki tabloda yer almaktadır. Buna göre; devlet düzenlemeleri ve kanunlardaki belirsizlik (DÇ3), alacak riski (TA4), makroekonomik belirsizlik (DÇ2), beklenmedik/geçici müşteriler (TA1) ve talepte önemli tahmin hataları (TA2) maddelerinin ilk beş sırayı oluşturduğu ve çevresel ile talep kaynaklı risk faktörlerinin maddelerinin ön sıralarda yer aldığı görülmektedir. Risk grupları sıralaması da küçük bir farkla olasılık değerlerindeki sıralamayla benzerlik göstermektedir.

Tablo 7. Önem puanına göre risk grupları ve risk maddeleri sıralaması

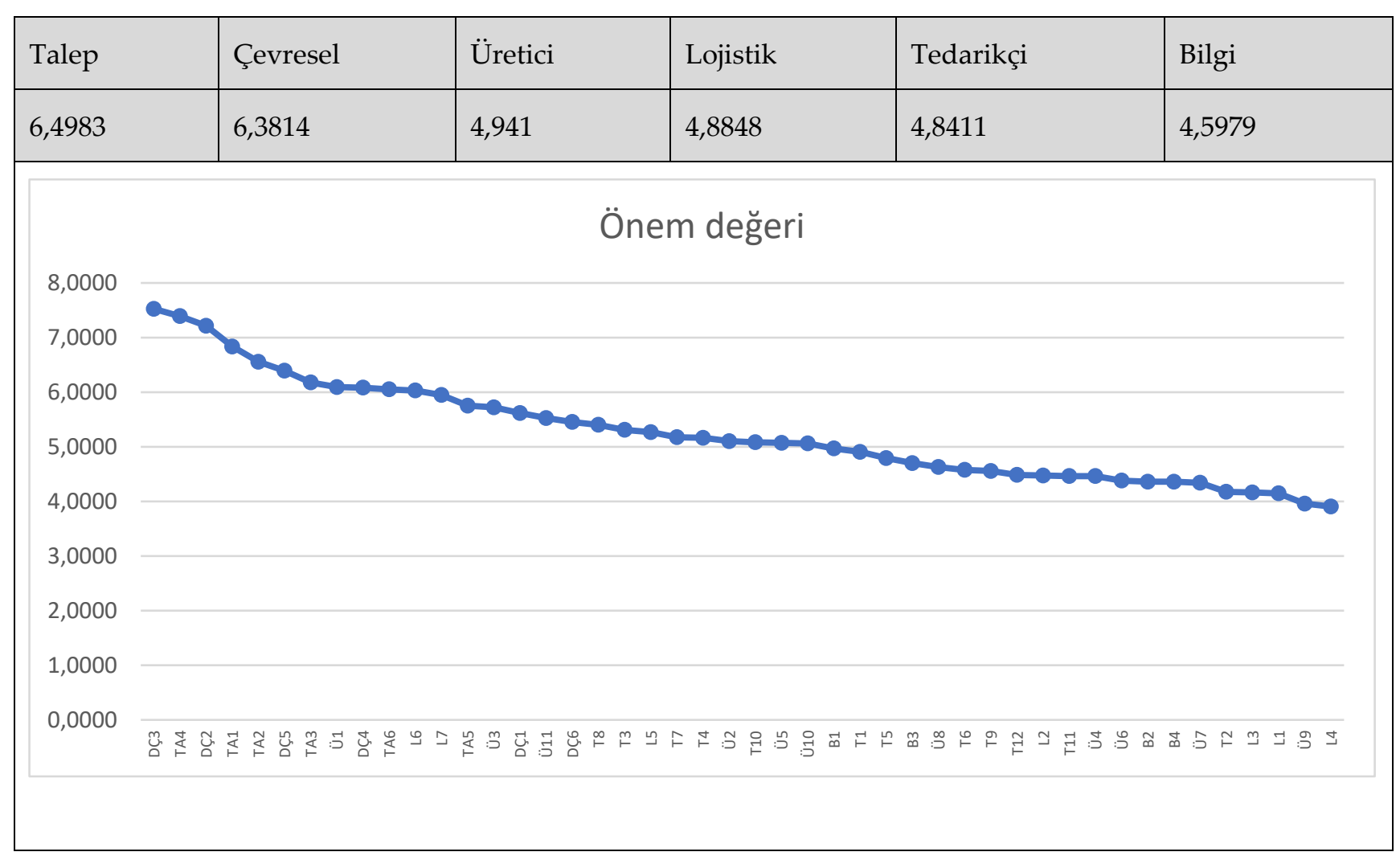

Sektör, işletme faaliyet yılı ve büyüklüğü açısından risk gruplarının olasıllk, etki ve önem derecelerine göre farklılık gösterip göstermediği araştırılmıştır. Yapılan Anova analizi sonucunda anlamlı bir farklılık bulunamamiştır. ( $\mathrm{p}>0,05)$

\section{SONUÇ VE DEĞERLENDİRME}

İşletmeler geçmişten günümüze artan dış kaynak bağımlılığı ile birlikte bir taraftan temel yeteneklerine daha iyi odaklanmakta ve bu sayede rekabet avantajı, etkinlik ve verimlilik hedeflerinde başarılı olmakta, diğer yandan ise işletme dışı tedarik zinciri üyelerine bağımlılıkları artarak bu durumdan kaynaklanan belirsizlik, aksamalar gibi olumsuz durumlarla karşılaşmaktadırlar. Yönetim açısından bakılacak olursa, tedarik zinciri risklerinin yönetilmesinde tedarik zinciri yöneticilerinin sorumluluğu her geçen gün artmaktadır. Bu nedenle, önemli risklerin belirlenmesi, değerlendirilmesi, doğru yöntemlerle yönetilmesi, düzenli aralıklarla gözden geçirilmesi ve bu çalışmaların işletme genelinde tüm çalışanların belirli noktalarda dahil edildiği bütüncül bir bakış açısı ile gerçekleştirilmesi gerekmektedir. Tedarik zinciri risk yönetiminin de temel amacı budur. Tedarik zinciri risklerinin gruplandırılarak önceliklendirilmesi ile üst yönetimin öncelikli riskler üzerine odaklanması ve bu doğrultuda planlama yaparak yönetmesi mümkündür.

Son yıllarda tedarik zinciri risklerine odaklanan birçok çalışma yayınlanmıştır. Bu çalışmalar tedarik zinciri risklerini tanımlamakta ve sinıflandırmaktadır (Heckmann vd., 2015; Hudnurkar vd., 2017; Musa, 2012; Punniyamoorthy vd., 2013; Singhal vd., 2011). Yöneticilerin tüm risklere aynı anda odaklanabilmesi için hem zaman hem de maliyet kısıtı olduğundan bu risklerin önceliklendirilmesi büyük önem taşımaktadır. Bu nedenle bu çalışmada, ilk olarak kapsamlı bir literatür araştırması ile tedarik zincirinde yer alan riskler tespit 
edilerek gruplandırılmıştır. Daha sonra, üretim sektöründe faaliyet gösteren 97 işletmenin katılımıyla gerçekleştirilen anket çalışması ile elde edilen veriler kullanılarak tedarik zinciri risklerinin olasılık ve etki değerleri kullanılarak önem puanları hesaplanmış ve hem risk grupları hem de her bir risk grubunu oluşturan maddeler sıralanmıştır. Toplam 46 risk maddesi 6 temel risk grubu altında sinıflandırılmıştır. Kullanılan ölçüm modelinin yüksek düzeyde geçerlilik ve güvenilirlik değerlerine sahip olduğu bulunmuştur. Hiçbir maddenin ilgili risk grubundan düşük faktör yükü ve benzeri bir sebeple çıarılmasına gerek kalmamıştır.

Çalışmalar genellikle yüksek olasılık ve düşük etkiye sahip risklere odaklanmakta, düşük olasılık ve yüksek etkiye sahip riskleri göz ardı etmektedirler. Bunun nedeni seyrek risk durumları için gerekli tahminleri yapmaya yönelik yeterli verinin mevcut olmayışıdır. (Er Kara \& Oktay Fırat, 2017: 49). Ancak önem değeri bakımından düşünüldüğünde her iki durum da benzer önem değerlerine sahip olacaklardır. Bu nedenle işletmelerin sadece olasılık veya etki değerine tek taraflı olarak bakması yerine, bir takım tahmin yöntemlerini kullanarak gerçeğe yakın olasılık ve etki değerleri kullanarak önem puanı hesaplaması ve önem puanları üzerinden riskleri önceliklendirerek yönetim teknikleri geliştirmesi tavsiye edilmektedir.

$\mathrm{Bu}$ çalışmanın, tedarik zinciri risklerini tanımlayıp gruplandırarak ve olasılık, etki ve önem puanları doğrultusunda risk unsurları açısından bir sıralama yaparak tedarik zinciri yönetimi ve risk yönetimi literatürüne katkı yaptığı düşünülmektedir. Elde edilen sonuçlar değerlendirildiğinde, talep kaynaklı ve çevresel kaynaklı risk gruplarındaki risklerin ilk sıralarda bulunduğu sonucuna ulaşılmıştır. Özellikle talep kaynaklı risk grubunda bulunan alacak riski olasılık, etki ve önem puanları açısından ilk beş risk faktörü arasında yer almıştır. Ek olarak, yine talep kaynaklı risklerden beklenmedik / geçici müşteriler ile çevresel kaynaklı risk grubundan makroekonomik belirsizlik ile devlet düzenlemeleri ve kanunlardaki belirsizlik risklerinin hem olasılık hem de önem puanları için ilk beş risk faktörü arasında bulunduğu görülmüştür. Etki değerleri incelendiğinde ise, talep ve çevresel kaynaklı riskler benzer şekilde yine ilk sıralarda yer alırken, üretim kaynaklı risk faktörlerinden üretimin durması riski ilk sırada bulunmaktadır.

Söz konusu çalışmada üretim sektöründe yer alan işletmelerden elde edilen veriler doğrultusunda birtakım bulgulara ulaşılmıştır. İleriki çalışmalarda, farklı sektörler için de tedarik zinciri risklerinin belirlenmesi, risk yönetim teknikleri ve işletme performansına etkileri konusunda yeni çalışmalar yapılmasının faydalı olacağı düşünülmektedir.

\section{KAYNAKLAR}

Blackhurst, J. V., Scheibe, K. P., \& Johnson, D. J. (2008). Supplier Risk Assessment and Monitoring for the Automotive Industry. International Journal of Physical Distribution \& Logistics Management, 38(2), 143165. https://doi.org/http://doi.org/10.1108/09600030810861215

Blos, M. F., Quaddus, M., Wee, H. M., \& Watanabe, K. (2009). Supply Chain Risk Management (SCRM): A Case Study on the Automotive and Electronic Industries in Brazil. Supply Chain Management, 14(4), $247-252$.

Bowersox, D., Closs, D. J., \& Cooper, M. B. (2002). Supply Chain Logistics Management (2. Baskı). Mc Grawhill.

Büyüközkan, G. (2008). Tedarik Zincirinde Risk Yönetimi. Lojistik Dergisi, (8).

Ceritoğlu, A. (2018). Tedarik Zinciri Kapsamında Risk Yönetimi. Içinde S. Schöning, E. H. Sümer Göğüş, \& H. Pernsteiner (Ed.), İşletmelerde Risk Yönetimi. İstanbul: İstanbul Bilgi Üniversitesi Yayınları.

Chopra, S., \& Meindl, P. (2004). Supply Chain Management (2. Bask1). Pearson Education International.

Chopra, S., \& Sodhi, M. S. (2004). Managing Risk to Avoid Supply-Chain Breakdown. MIT Sloan Management Review, 46(1), 52-61.

Christopher, M., \& Peck, H. (2004). Building the Resilient Supply Chain. International Journal of Logistics Management, 15(2), 1-13.

Demirci Orel, F., \& Akkan, E. (2018). Tedarik Zincirinde Risk, Risk Yönetimi ve Performans İlişkileri: Bir Literatür Taraması. Beykoz Akademi Dergisi, $\quad 6(1), \quad 84-117$. https://doi.org/10.14514/BYK.m.21478082.2018.6/1.84-117

Demirkol, İ., Ünğan, M. C., \& Ayanoğlu, M. (2015). Tedarik Zinciri Risklerinin İşletme Performansı Üzerindeki 
Etkisi : Otomotiv Sektöründe Bir Uygulama. İşletme Bilimi Dergisi, 3(1), $20-37$.

Er Kara, M., \& Oktay Fırat, S. Ü. (2017). Tedarik Zinciri Riskleri: Literatür Taraması ve Yeni Bir Sınıflandırma. Beykent Üniversitesi Fen ve Mühendislik Bilimleri Dergisi, 10(1), 31-60.

Faizal, K., \& Palaniappan, P. K. (2014). Risk Assessment and Management in Supply Chain. Global Journal of Researches in Engineering, 14(2), 19-30.

Gunasekaran, A., Patel, C., \& McGaughey, R. E. (2004). A Framework for Supply Chain Performance Measurement. International Journal of Production Economics, 87(3), 333-347.

Heckmann, I., Comes, T., \& Nickel, S. (2015). A Critical Review on Supply Chain Risk-Definition, Measure and Modeling. Omega, (52), 119-132.

Hudnurkar, M., Deshpande, S., Rathod, U., \& Jakhar, S. K. (2017). Supply Chain Risk Classification Schemes : A Literature Review. Operations and Supply Chain Management, 10(4), 182-199. https://doi.org/10.31387/oscm0290190

Jüttner, U., Peck, H., \& Christopher, M. (2003). Supply Chain Risk Management: Outlining An Agenda For Future Research. International Journal of Logistics : Research \& Applications, 6(4), 197-210.

Keskin, H. (2015). Tedarik Zinciri Yönetimi - Arka Planı, Gelişimi ve Güncel Uygulamaları (1. Baskı). Ankara: Nobel Yayınevi.

Lambert, D. M., Cooper, M. C., \& Pagh, J. D. (1998). Supply Chain Management: Implementation Issues and Research Opportunuties. International Journal of Logistics Management, 9(2).

Lee, H. L., Padmanabhan, V., \& Wang, S. (1997). Information Distortion in a Supply Chain: The Bullwhip Effect. Management Science, 43(4), 546-558.

Manuj, I., \& Mentzer, J. T. (2008). Global Supply Chain Risk Management Strategies. International Journal of Physical Distribution \& Logistics Management, 38(3), 192-223.

Musa, N. S. (2012). Supply Chain Risk Management: Identification, Evaluation and Mitigation Techniques. Linköping University.

Nagurney, A., Cruz, J., Dong, J., \& Zhang, D. (2005). Supply Chain Networks, Electronic Commerce, and Supply Side and Demand Side Risk. European Journal of Operational Research, (164), 120-142.

Özgüner, M., \& Özgüner, Z. (2019). Tedarik Zinciri Riskleri'nin Lojistik Performans Üzerindeki Etkisinin Yapısal Eşitlik Modellemesi ile Belirlenmesi. Eskişehir Osmangazi Üniversitesi İktisadi ve İdari Bilimler Dergisi, 14(1), 67-82. https://doi.org/10.17153/oguiibf.437166

Özsoy, M. T. (2012). Yenï Türk Tïcaret Kanunu ve Şïrketlerde Kurumsal Rïsk Yönetïmï. İSMMMO Mali Çözüm Dergisi, Mart-Nisan, 165-186.

Punniyamoorthy, M., Thamaraiselvan, N., \& Manikandan, L. (2013). Assessment of Supply Chain Risk : Scale Development and Validation. Benchmarking: An International Journal, 20(1), 79-105. https://doi.org/10.1108/14635771311299506

Rogers, H., Srivastava, M., Pawar, K. S., \& Shah, J. (2016). Supply Chain Risk Management in India - Practical Insights. International Journal of Logistics Research and Applications, 19(4), 278-299. https://doi.org/10.1080/13675567.2015.1075476

Sharma, S. K., \& Bhat, A. (2012). Identification and Assessment of Supply Chain Risk: Development of AHP Model for Supply Chain Risk Prioritisation. International Journal of Agile Systems and Management, 5(4), 350-369. https://doi.org/10.13140/2.1.2648.1286

Singhal, P., Agarwal, G., \& Mittal, M. L. (2011). Supply Chain Risk Management: Review, Classification and Future Research Directions. International Journal of Business Science and Applied Management, 6(3), 1542.

Tang, C. S. (2006). Perspectives in Supply Chain Risk Management. International Journal of Production Economics, 103, 451-488. https://doi.org/10.1016/j.ijpe.2005.12.006 
Tang, C., \& Tomlin, B. (2008). The Power of Flexibility for Mitigating Supply Chain Risks. International Journal of Production Economics, 116(1), 12-27.

Tang, O., \& Nurmaya Musa, S. (2010). Identifying Risk Issues and Research Advancements in Supply Chain Risk Management. International Journal of Production Economics, 124(1), 109-120.

Walker, P. L., Shenkir, W. G., \& Barton, T. L. (2002). Enterprise Risk Management: Pulling It All Together. The Institute of Internal Auditors Research Foundation Publicaion.

Wang, M., Jie, F., \& Abareshi, A. (2014). The Measurement Model of Supply Chain Uncertainty and Risk in the Australian Courier Industry. Operations and Supply Chain Management: An International Journal, (February 2019), 89-96. https://doi.org/10.31387/oscm0180114

World Economic Forum. (2012). New Models for Addressing Supply Chain and Transport Risk. Cenevre.

World Economic Forum. (2019). The Global Risks Report 2019: 14th Edition. Cenevre.

Yazıcı, M. (2018). İşletmelerde Risk Yönetimi ve Karar Verme (1. baskı). İstanbul: Beta Basım Yayım Dağıtım A.Ş.

Yolaç, G., Tuzcuoğlu, A., \& Şahin, M. (2019). Tedarik Zincirinde Risk Yönetimi ve Performans İlişkisi : İstanbul İlinde Bir Araştırma. Ekoist: Journal of Econometrics and Statistics, (31), 95-106. https://doi.org/10.26650/ekoist.2019.31.0015

Zsidisin, G. A., \& Ellram, L. M. (2003). An Agency Theory Investigation of Supply Risk M anagement. Journal of Supply Chain Management, 39(2), 15-27. https://doi.org/10.1111/j.1745-493X.2003.tb00156.x

Zsidisin, G., \& Wagner, S. (2008). Supply Risk Perceptions And Practices: An Exploratory Comparison Of German And US Supply Management Professionals. International Journal of Technology, Policy and Management, 8(4), 401-419. 


\section{EK: İŞLETMELERE UYGULANACAK ANKET FORMU}

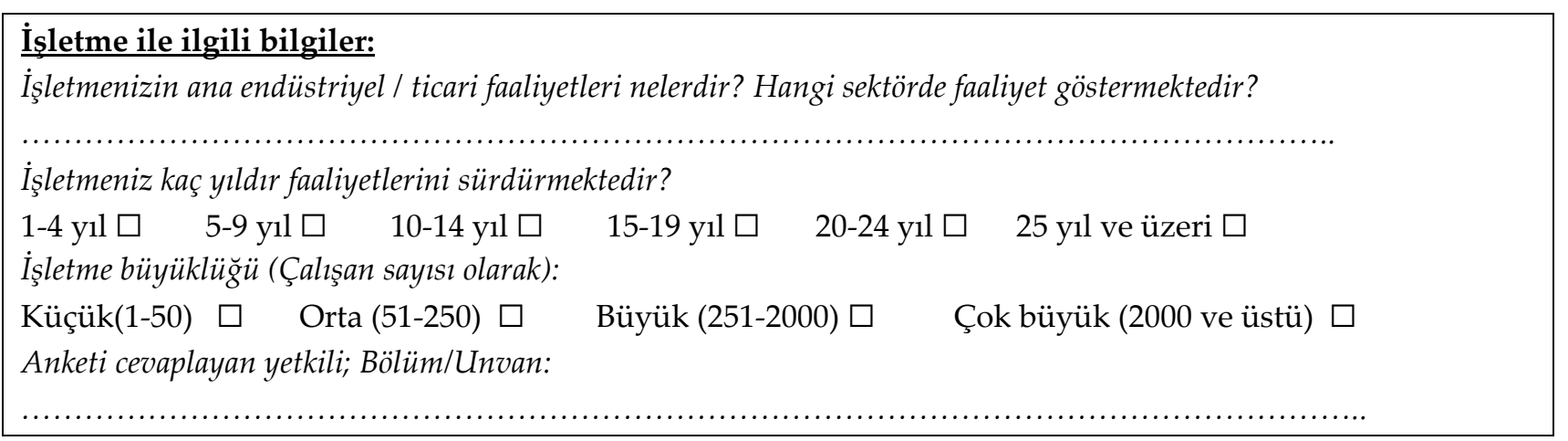

Aşağıda belirtilen tedarik zinciri risk faktörlerini meydana gelme olasılığı ve işletmenize etkisi açısından değerlendiriniz. Değerlendirirken aşağıdaki skalayı kullanınız

\begin{tabular}{|l|l|}
\hline Meydana gelme olasılığını değerlendirirken: & İşletmenize etkisini değerlendirirken: \\
& \\
1: Çok küçük $=>$ Yılda bir & 1: Çok hafif => Etkisi çok düşük \\
2: Küçük => Üç ayda bir & 2: Hafif $=>$ Sınırlı etkisi olan \\
3: Orta $=>$ Ayda bir & 3: Orta => Orta düzeyde etkisi olan \\
4: Yüksek => Haftada bir & 4: Ciddi => Ciddi /kalıcı etki yaratan \\
5: Çok yüksek => Hergün & 5: Çok ciddi => İşletmenin kapanmasına/iflasına \\
& neden olan \\
\hline
\end{tabular}

\begin{tabular}{|c|c|c|c|c|c|c|c|c|c|c|}
\hline \multirow[t]{2}{*}{ Tedarikçi kaynaklı risk faktörleri } & \multicolumn{5}{|c|}{$\begin{array}{l}\text { Meydana gelme } \\
\text { olasılığ }\end{array}$} & \multicolumn{5}{|c|}{$\begin{array}{l}\text { İşletmenize } \\
\text { etkisi }\end{array}$} \\
\hline & 1 & 2 & 3 & 4 & 5 & 1 & 2 & 3 & 4 & 5 \\
\hline 1. Tedarik edilen malzemenin kalitesiz olması & & & & & & & & & & \\
\hline 2. Belirsiz tedarikçi kabul / denetim prosedürü & & & & & & & & & & \\
\hline 3. Tedarikçinin eksik malzeme göndermesi & & & & & & & & & & \\
\hline $\begin{array}{l}\text { 4. Tedarikçinin esnek olmaması / değişen şartlara uyum } \\
\text { sağlayamaması }\end{array}$ & & & & & & & & & & \\
\hline $\begin{array}{l}\text { 5. Tedarikçi teknik bilgi eksikliği (üretim metodu, istenen özel } \\
\text { testlerin yapılması, ekipman, paketleme vb) }\end{array}$ & & & & & & & & & & \\
\hline $\begin{array}{l}\text { 6. Tedarikçinin teknik çizim, malzeme teknik döküman vb } \\
\text { sağlayamaması }\end{array}$ & & & & & & & & & & \\
\hline $\begin{array}{l}\text { 7. Tedarikçinin ani bir şekilde yükümlülüklerini yerine } \\
\text { getirememesi durumu }\end{array}$ & & & & & & & & & & \\
\hline $\begin{array}{l}\text { 8. Kritik ve uzun temin süresine sahip malzemeler için tek } \\
\text { tedarikçiye bağımlı olmak }\end{array}$ & & & & & & & & & & \\
\hline 9. Kritik malzemelerin tedarikçilerinin sıkça değişmesi & & & & & & & & & & \\
\hline 10. Malzeme temininin sıkça gecikmesi & & & & & & & & & & \\
\hline 11. Fikri mülkiyet riski (tedarikçi güvensizliği) & & & & & & & & & & \\
\hline 12. ritik malzemenin karmaşıklığ 1 & & & & & & & & & & \\
\hline \multirow[t]{2}{*}{ Üretici kaynaklı risk faktörleri } & \multicolumn{5}{|c|}{$\begin{array}{l}\text { Meydana gelme } \\
\text { olasılığı }\end{array}$} & \multicolumn{5}{|c|}{$\begin{array}{l}\text { İşletmenize } \\
\text { etkisi }\end{array}$} \\
\hline & 1 & 2 & 3 & 4 & 5 & 1 & 2 & 3 & 4 & 5 \\
\hline 1. Üretimin durması & & & & & & & & & & \\
\hline 2. Üretim sürecinde değişkenliğin yüksek düzeyde olması & & & & & & & & & & \\
\hline 3. Ürün üretim süresinin değişken olması & & & & & & & & & & \\
\hline
\end{tabular}




\begin{tabular}{|c|c|c|c|c|c|c|c|c|c|c|}
\hline 4. $\quad$ Yetersiz üretim kapasitesi & & & & & & & & & & \\
\hline 5. $\quad$ Kapasitenin esnek olmaması & & & & & & & & & & \\
\hline $\begin{array}{l}\text { 6. Serbest malzeme akışı için yerleşim düzeninin esnek } \\
\text { olmaması }\end{array}$ & & & & & & & & & & \\
\hline 7. Belirsiz denetim ve kabul prosedürleri & & & & & & & & & & \\
\hline 8. $\quad$ S1k ürün geri çağırma süreci & & & & & & & & & & \\
\hline $\begin{array}{l}\text { 9. Temel yeteneklerin kaybına neden olacak şekilde tasarım } \\
\text { vb dökümanların tedarikçilerle paylaşılması }\end{array}$ & & & & & & & & & & \\
\hline $\begin{array}{l}\text { 10. Stratejik depolar / envanterin düzgün olmayan şekilde } \\
\text { elleçlenmesi / bakımı }\end{array}$ & & & & & & & & & & \\
\hline 11. Organizasyonel konularla ilgili sorunlar & & & & & & & & & & \\
\hline Talep kaynaklı risk faktörleri & & eyd & & gel & & & kisi & & & \\
\hline & 1 & 2 & 3 & 4 & 5 & 1 & 2 & 3 & 4 & 5 \\
\hline 1. Beklenmedik / geçici müşteriler & & & & & & & & & & \\
\hline 2. Talepte önemli tahmin hataları & & & & & & & & & & \\
\hline 3. Müşteri sevkiyatında gecikmelerin çok olması & & & & & & & & & & \\
\hline 4. Alacak riski & & & & & & & & & & \\
\hline 5. Müşteri tercihlerinde değişim & & & & & & & & & & \\
\hline 6. İtibar riski & & & & & & & & & & \\
\hline Lojistik kaynaklı risk faktörleri & & eyd & & & & & letn & & & \\
\hline & 1 & 2 & 3 & 4 & 5 & 1 & 2 & 3 & 4 & 5 \\
\hline $\begin{array}{l}\text { 1. Lojistik işletmesinin operasyon/finansal gücünün yetersiz } \\
\text { olması }\end{array}$ & & & & & & & & & & \\
\hline 2. $\quad$ Depolama sorunları & & & & & & & & & & \\
\hline 3. Dağıtım ağının kötü tasarlanmış olması & & & & & & & & & & \\
\hline Taşıma modunun yanlış seçimi & & & & & & & & & & \\
\hline 5. Düzgün olmayan paketleme ve işaretleme & & & & & & & & & & \\
\hline 6. Düzgün olmayan istifleme/kaza nedeniyle hasar oluşması & & & & & & & & & & \\
\hline 7. Sevkiyat sürecinde gecikme & & & & & & & & & & \\
\hline Bilgi kaynaklı risk faktörleri & & eyd & & gel & & & kisi & leni & & \\
\hline & 1 & 2 & 3 & 4 & 5 & 1 & 2 & 3 & 4 & 5 \\
\hline $\begin{array}{l}\text { 1. İşletme içinde veya dışında bilgi ve iletişim altyapısının } \\
\text { kullanılamaması / gecikmeler }\end{array}$ & & & & & & & & & & \\
\hline 2. İç /dış bilgi işlem altyapısında çökmeler & & & & & & & & & & \\
\hline 3. Bilgi sistemlerinde yetersiz güvenlik & & & & & & & & & & \\
\hline 4. İletişim / bilgi paylaşım ortamının yanlış seçimi & & & & & & & & & & \\
\hline İşletmenin dış çevresindeki risk faktörleri & & eyd & & gel & & & $\begin{array}{l}\text { letn } \\
\text { kisi }\end{array}$ & & & \\
\hline & 1 & 2 & 3 & 4 & 5 & 1 & 2 & 3 & 4 & 5 \\
\hline 1. Belirsiz politikalar & & & & & & & & & & \\
\hline 2. $\quad$ Makroekonomik belirsizlik & & & & & & & & & & \\
\hline Devlet düzenlemeleri ve kanunlardaki belirsizlik & & & & & & & & & & \\
\hline 4. Sosyal belirsizlik & & & & & & & & & & \\
\hline 5. Kalifiye gücünün olmayışı & & & & & & & & & & \\
\hline $\begin{array}{l}\text { 6. Savaş, terörizm, doğal afetler, grev, ayaklanma gibi elde } \\
\text { olmayan etmenler }\end{array}$ & & & & & & & & & & \\
\hline
\end{tabular}

Kaynak: Punniyamoorthy, M., Thamaraiselvan, N., \& Manikandan, L. (2013). Assessment of Supply Chain Risk: Scale Development and Validation. Benchmarking: An International Journal, 20(1), 79-105. https://doi.org/10.1108/14635771311299506 